\title{
VULNERABILITIES AND THREATS TO HUMAN SECURITY GENERATED BY AN INEFFECTIVE EDUCATIONAL SYSTEM
}

\author{
Rareș MACREA*, Petronela MACREA** \\ *"Babeș-Bolyai" University of Cluj Napoca, Romania \\ **6"Lucian Blaga" University of Sibiu, Romania \\ rares.macrea@me.com
}

\begin{abstract}
The present trend towards globalization has led to people changing their views on possible threats to their existence. Nowadays, we witness a diversification of vulnerabilities and threats to human security, as well as a progressive reduction of our resilience. The article attempts to correlate the 5 dimensions of national security, as identified by the Copenhagen School of Security, with the problems of the Romanian educational system, explaining how these problems can become threats to the security of Romanian citizens. It offers an overview of the problems of the Romanian educational system, and the threats and vulnerabilities derived from them towards human security. It also suggests solutions to problems and indicators for monitoring progress.
\end{abstract}

Keywords: human security, vulnerabilities, threats, education

\section{Introduction}

The 21st century has shown since its beginning an increase of the globalization trend, which has been leading to changes regarding the individual perception on the threats towards their security. We witness diversification of threats as well as reduced predictability regarding their complexity.

In order to draw attention to this complexity and also to individuals reduced ability to manage the present threats, Nassim Nicholas Taleb - in the book named Black swan - The Inpact of the Highly Inprobable, suggests the need to change the individuals way of thinking, making the following inquiries:

"What did people learn from the 9/11 episode? Did they learn that some events, owing to their dynamics, stand largely outside the realm of the predictable? No. Did they learn the built-in defect of conventional wisdom? No. What did they figure out? They learned precise rules for avoiding Islamic prototerrorists and tall buildings....

Why? It is necessary here, as it is my agenda in the rest of this book, both to stand conventional wisdom on its head and to show how inapplicable it is to our modern, complex, and increasingly recursive environment."[1]

\section{The new security concept}

The basic word „security" comes from the Latin Securitas, which translates as ,no worries”, ,soul tranquility”. [2]

In 1952, Arnold Wolfers defined security as ,objectively, the absence of threats towards the acquired values, and subjectively - the absence of fear to have these values under attack". [3]

Nowadays, the Romanian theoreticians suggest the following definition:

„The individual / common condition of person / community / nation and of the local / national / international social organizations, in the absence of risks, 
threats, dangers, defiances and nonmilitary agressions towards the common national values and interestes, as well as the guarantee that they will not be at risk under any circumstances" [4]

Although there is no definition unanimously accepted, the human individual is both the topic and the reference object of the security concept. Any social structure is based on individuals, (ex. The nation, organized in a country community, cities / villages, families, as specific forms of living) globalization leading to standardized values and interestes of individuals.

„The individual, as the main element of society, represents the source and resource of any social organization. The individual national security, as identical reference objects in the matter of security theory and practice.

The new-realist Barry Buzan identifies 5 dimensions of modern security, which are agreed upon by the majority of specialists. [6]

The 5 dimensions are:

The military dimension

The political dimension

The economic dimension

The social dimension

The environment dimension

The security status - the preception upon the absence of threats towards human values - is represented by the interaction of all the 5 dimensions.

On the chart of interaction of the 5

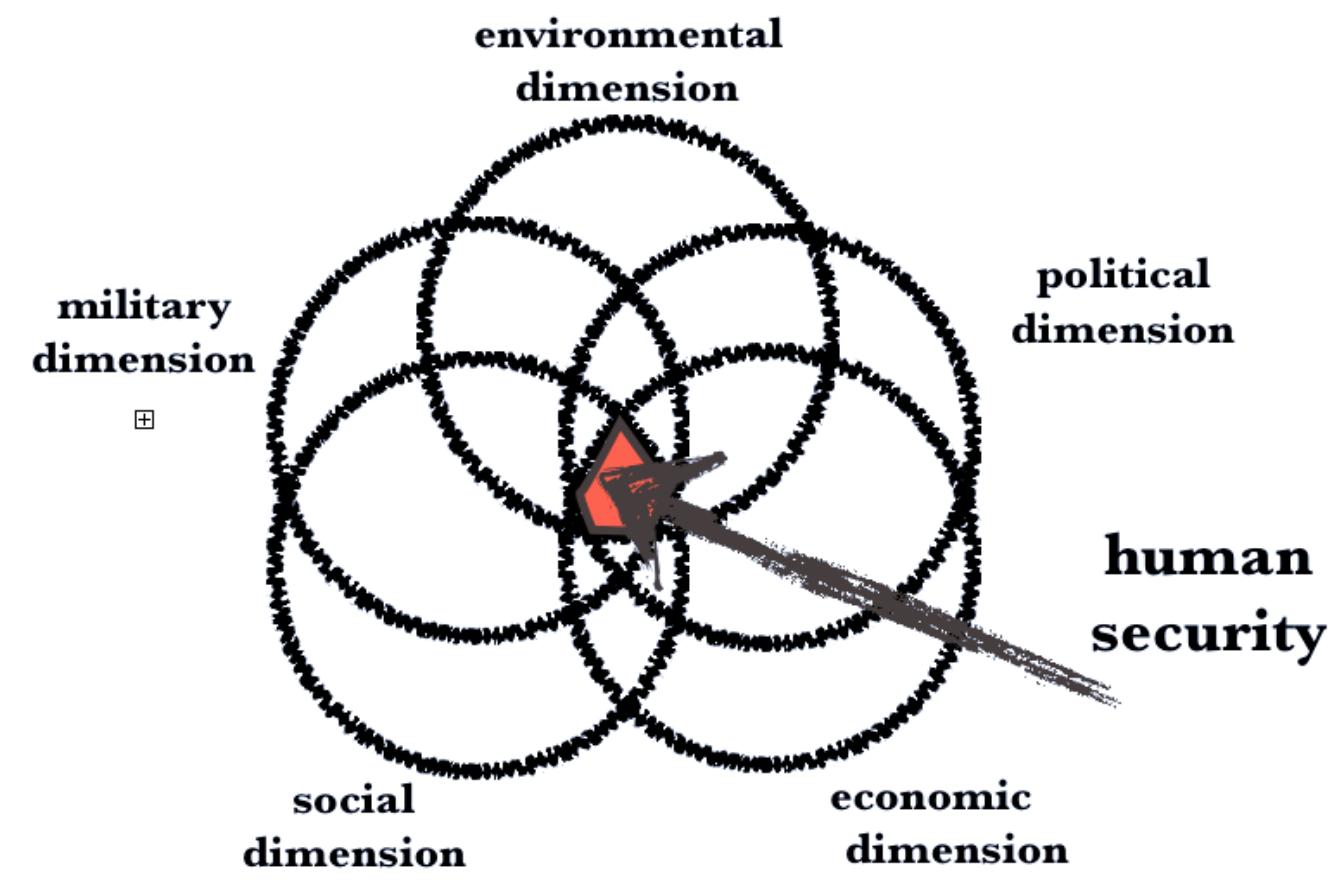

Figure 1: Interactions between 5 dimensions of human security (R. Macrea)

transcends all borders between the fields and levels of the social system, ,[5]

Based on the analysis of the international security context at the end of 20th century - when the military aggression was not the main threat to security - the School of Copenhagen suggests a new approach, by placing the human security next to the dimensions, if 3 of them (the ecologic, the social and the economic component) are separated from the others, we can identify the elements compiling the concept of sustainable development. Thus, we will use the key indicators as established by the UE to measure the degree of accomplishment of the sustainability 
objectives within UE member countries.

UE has established more than 100 indicators regarding the sustainable development objectives, out of which there are 9 indicators referring to the education level in the member states, as follows:

- Early leavers from education and training;

- Tertiary educational attainment, by sex, age group 30-34;

- At-risk-of-poverty rate, by highest level of education attained;

- At most lower secondary educational attainment by age;

- Lifelong learning;

- Low reading literacy performance of pupils;

- Individuals' level of computer skills;

- Individuals' level of internet skills;

- Public expenditure on education (for sub-theme Education)

All 9 educational indicators are subordinated to a key indicator - Social inclusion. [7]

Thus, education is directly connected to the new security concept, through the social dimension.

By analysis of Romanian indicators (as UE member state), we conclude that Romanian educational system is constantly at the bottom of international classifications, with descending trends.

The college international tops do not include any Romanian colleges in the first 500 positions.

An educational system that is ineffective generates vulnerability regarding the citizens' safety, contributing to social exclusion, corruption, demographic decline, brain drain. [8]

The experts in education issues have identified 11 key problems that generate vulnerability regarding human security. [9]

\section{Problems regarding the Romanian educational system}

Studies of education experts identified 10 key issues that generate vulnerability to human security: [9]

1. Low administrative capacity of the
Ministry of National Education

2. Financing weak and ineffective

3. Insufficient use of research based on empirical data in the creation of educational policies

4. Define, operational and stimulating poor educational performance

5. Poor recruitment and motivation of education

6. High levels of inequality of school opportunities

7. The high dropout rate

8. 8.Learning deficient rules and democratic skills

9. Use small open educational resources and limited access to publicly funded research results

10. Educational policies less adapted to a dynamic demographic context and a changing labour market

\section{Vulnerabilities}

Derived from weak administrative capacity of state institutions with responsibilities in education manifests some vulnerabilities: using European funds, public financing of education and scientific research. Also it has negative effects and failure Education Law art. 223, paragraph 5 which provides multiannual financing of education.

Shortages motivators for Romanian researchers and experts to produce publications and to coordinate research relevant to public policy development leads to another vulnerability on the Romanian education system's inability to generate and implement public policies consistent.

Corruption cases of plagiarism, involving decision makers in the education system make vulnerabilities, generating negative impact on the credibility and image of our country.

A number of vulnerabilities arise from chronic poverty, which leads to increased dropout, massive migration, lack of citizenship and negative demographic trends.

Because the educational system not to generate security threats and vulnerabilities 
to Romanian citizens need emergency: His specialize / professionalise the development of training programs for managers of educational institutions and boards to increase institutional capacity

His take account of trends and strategies for sustainable development and creating a vision of the country for long-term education to include education as a priority in national strategies

\section{Conclusions}

The strength of a nation is not exclusively based on military component anymore, it acts in connection with other 4 dimensions in a new concept of ,smart power", bringing education in direct connection with the new concept of human security. We presently face events that threat the values acquired among generations, and endanger the personal and common interests, due to our assumptions that these events should not occur.

The role of a modern educational system is to change the present thinking patterns, which are now fit for an environment with simple causes and simple effects and with slow information spread.

The mission of school is to adapt to the new reality of a more recursive environment, with an increasing number of response cycles.

[1] Nassim Nicholas Taleb, The Black Swan- The Inpact of the Highly Inprobable, Bucharest, Curtea veche, 2010 pp. 20

[2] http://www.etymonline.com/index.php?term=secure

[3] Buzzan, Barry. Popoarele, statele şi teama, Ediţia a doua, Chişinău, Editura Cartier, 2000, pp. 29.

[4] Gabriel Oprea; Radu Timofte şi Constantin Onişor, România-integrare şi securitate, Bucureşti, Editura Balcanii şi Europa, 2005, pp. 28-29.

[5] Helene VIAU, La théorie critique et le concept de sécurité en Rélations internationales, http://www.er.uqam.ca/nobel/cepes/

[6] Barry Gordon Buzan (born 28 April 1946) is Emeritus Professor of International Relations at the London School of Economics and honorary professor at the University of Copenhagen and Jilin University. Until 2012 he was Montague Burton Professor of International Relations at the LSE. Buzan sketched the Regional Security Complex Theory and is therefore together with Ole Wæver a central figure of the Copenhagen School. https://en.wikipedia.org/wiki/Barry_Buzan

[7] http://ec.europa.eu/eurostat/web/sdi/indicators/social-inclusion

[8] Gabriel Bădescu and Anca Sinea, Education, Good governance, National security Centrul pentru Studiul Democrației, Cluj Napoca, 2016, pp 7;

[9] http://democracycenter.ro/application/files/6114/5882/9169/agenda.pdf 